\title{
中国・日本の被験者による地域景観の注視特性と評価構造に関する分析 FIXATION BEHAVIOR AND EVALUATION STRUCTURE OF REGIONAL LANDSCAPE BY CHINESE AND JAPANESE STUDENTS
}

\author{
西名大作，村川三郎**，金華***，大石洋之**** \\ Daisaku NISHINA, Saburo MURAKAWA, Hua JIN \\ and Hiroshi OISHI
}

\begin{abstract}
Cross-cultural background represents an influential element in the evaluation of environment and landscape. The purpose of this study was to clarify differences and similarities between Chinese and Japanese students in Hiroshima University regarding visual information processing in landscape evaluation. Eye-movements of subjects were measured during the presentation of regional landscape slides. Each slide comprised three landscape elements. These elements were controlled independently by image processing. Fixation behavior and psychological evaluation were compared between subject groups. The characteristics of fixation behavior were found to be basically the same between groups. With regard to familiar elements, correlations between eye-movements and evaluation were low in each group. However, with regard to unfamiliar elements, different correlations were observed in each group, attributable to differences in visual experience and knowledge.
\end{abstract}

\author{
Keywords: Cross-culture, Eye-movement, Eye Camera, Psychological Evaluation, \\ Component Element, Landscape \\ 異文化, 眼球運動, アイカメラ, 心理的評価, 構成要素, 地域景観
}

\section{1. 序}

景観評価に影響を及ぼす諸要素のなかで，評価者の個人差はよく 指摘されている。この個人差には, 性別, 年齢, 職業などの個人的 な属性のほか，民族，言語，文化，宗教などに起因する生育環境の 人文学的・社会学的な背景の違いや, 気候や風土, 自然植生など生 育環境の物理的条件の違いも含まれており，環境や景観に対する評 価・判断の基準や選好性は，評価者のこれまでの日常的な生活経験 の全てによって培われると考えられる。

このような個人差による影響を検討する試みの一つに，評価者が 様々な生活経験をその中で蓄積する広範な生育環境として, 国とい う枠組みの違いに着目する立場がある。国の違いは上述した人文学 的・社会的背景や物理的環境条件の顕著な相違を代表し, 個人差を 検討する上で重要な視点を提供する。単一民族国家の日本では，こ のような観点からの研究蓄積は, 鈴木ら ${ }^{1)}$ や杉尾 ${ }^{2)}$, 岡島ら ${ }^{3) ~-5) ~}$ など，未だそしいが，国や地域が地理的に連続し言語障壁の低い欧 米諸国では，生育環境の地域的な隔たりに着目した研究を，広義の 異文化間比較（cross-cultural comparison）研究として，早くから関心 が注がれている。

基本的には，文化の相違が環境や景観に対する美的感覚，審美的 評価に及ぼす影響は極めて大きいと主張する Lowenthal ${ }^{6)} や$ Tuan $^{7}$
の考え方があり, その実証研究としての Sonnenfeld ${ }^{8}$ がある一方で, 異文化間の共通性を主張する Ulrich ${ }^{9) や, ~ S h a f e r ~ \& ~ T o o b y ~}{ }^{10)}$, Zube \&

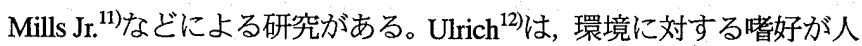
間の原初的な環境適応の所産なら, 人間という生物種に共有される はずであること，視知覚情報処理系に例えば人種などによる生物学 的な差異が存在しないこと, メディアや交通の発達により視覚的経 験が豊富に蓄積されていることなどを理由として挙げている。

このような両者の対立を経て現在は, 異文化間の相違性と共通性 をともに認めた上で, それらの程度や要因の探求に主眼が移行し, 多面的な検討が行われるようになってきている。例えば, 東洋と西 洋の相違に着目した Tips \& Sabasdisara ${ }^{13)}{ }^{3} \mathrm{Nasar}^{14)}$, Yang $5^{15), 16)}$, 出身国の相違と他の属性との比較を試みた Kaplan \& Herbert ${ }^{17}$ や $\mathrm{Yu}^{18)}$, Herzog $5^{19)}$ のほか, Purcell $5^{20)}$ は, 環境と対峙した際の評価 者の観点による影響を, Peron ら ${ }^{21)}$ は評価者の環境に対する慣れ親 しみ（Familiarity）による影響をそれぞれ取り上げている。

このような出身国の相違による異文化間の比較研究として, 筆者 らも留学生を対象とした意識調査に基づき, 生活環境評価や, みど り環境との関連性からみどり景観への評価について分析し, 出身国 の社会・文化的背景や，自然環境の様相による影響を見いだしてい る ${ }^{22)}$. 23)。さらに, 英国・日本・中国在住の被験者による国内外河
* 広島大学大学院工学研究科 助教授 ·博士 (工学)

** 広島大学大学院工学研究科 教授. 工博

*** 大連民族学院 博士 (工学)

$* * * *$ 広島大学大学院工学研究科 大学院生
Assoc. Prof., Graduate School of Engineering, Hiroshima Univ., Dr. Eng. Prof., Graduate School of Engineering, Hiroshima Univ., Dr. Eng. Dalian Nationalities Univ., Dr. Eng.

Graduate Student, Graduate School of Engineering, Hiroshima Univ. 
川景観の評価実験結果からは，景観の物理的特性と心理的評価との 関連性について，生育環境の相違による影響を検討している ${ }^{24) 。}$

しかしながら，以上の研究では，評価者が所与の景観から情報を 収集し, 最終的な判断に至るまでの認識・評価プロセスにおける視 知覚的生理反応である眼球運動についての, 出身国による相違の検 討は未だ行われていない。評価者の過去の経験によって, この一連 のプロセスにおける時々刻々の眼球運動は左右され，例えば，瞹昧 な対象や, 未知の対象に対する視線の軌跡と, 頻繁に視覚体験のあ る，見慣れた対象に対する軌跡とでは異なる可能性が存在する。評 価者の出身国という生育環境の違いによって景観に対する認知の態 様にも相違が夕られるなら, 認識・評価プロセスからの最終的な出 力として得られる心理的評価における差異を解釈する上で, その情 報は有用と考えられる。

このような観点から本研究では, 広島大学に在籍する日本人大学 生と中国人留学生を被験者として, 現在の居住地である東広島市の 地域景観をべースとした合成画像を呈示し，心理的評価を求めると ともに，景観を眺める際の眼球運動を測定する実験を行った。これ により, 視覚体験が異なると予想される事物（景観構成要素）の変 化について, 日本人大学生と中国人留学生における心理的評価およ び注視特性の相違を把握し, 両者の関連を比較することによって, 評価者の出身国の相違が，景観の認識・評価プロセスに及ぼす影響 の諸相を検討することを目的としている。

なお, 評価者の注視特性という側面から, 景観の心理的評価の特 性を明らかにすることを試みた研究としては, 藤井ら ${ }^{25)}$ が植物の色 彩, 古谷ら ${ }^{26)}$ が景観に含まれている建物の配置の変化, さらに筆者 ら ${ }^{27), 28)}$ も画像に含まれる要素やその特徴量などを扱っている。事 例は少ないが，これら研究の多くは，評価される景観の物理的特性 に着目し, 注視特性との関連を検討しており, 本研究のように, 注 視特性と心理的評価との関連における, 評価者の社会・文化的背景 の及ぼす影響について検討したものはみられない。

\section{2. 実験概要}

\section{1 呈示景観の内容}

景観に含まれている各構成要素に対する視覚体験が注視特性およ び心理的評価へ及ぼす影響を検討するため, 本研究では景観に含ま

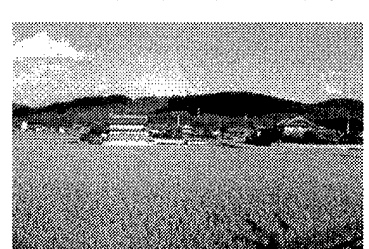

整形な田十伝統的な家十山あり

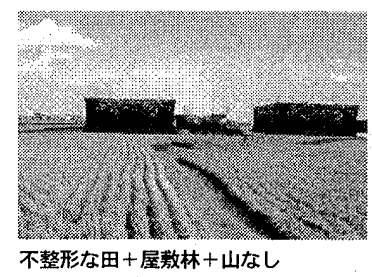

不整形な田十屋教林十山なし 写真 -1 呈示詈観写真の例

表一2 実験の手順と所要時間

\begin{tabular}{|c|c|c|}
\hline & \multicolumn{2}{|c|}{ 所要時間 } \\
\hline & 日本人大学生 & 中国人留学生 \\
\hline 実験全体説明 & 3分 & 5分 \\
\hline フェースシート記入 & 5分 & 5分 \\
\hline EMR装着 & 10分 & 10分 \\
\hline キかリブレーション & 5分 & 5分 \\
\hline 無地スライト & 30秒 & 15秒 \\
\hline 景観スライト & 30秒 $\times 7$ & 30秒 \\
\hline 無地スライト & 30 秒 & 15秒 \\
\hline キャリフプレーション & 1分 & \\
\hline 量観評価説明 & 2分 & \\
\hline 各緊観評価 & 3分 & 3分 \\
\hline 合計時間 & 63分30秒 & 83分 \\
\hline
\end{tabular}

\begin{tabular}{|c|c|c|c|c|c|}
\hline \multicolumn{4}{|c|}{ 回答 - 評価項目 } & $\begin{array}{l}\text { 日本人 } \\
\text { 大学生 }\end{array}$ & $\begin{array}{l}\text { 中国人 } \\
\text { 留学生 }\end{array}$ \\
\hline \multirow[t]{2}{*}{$\begin{array}{l}\text { 被験 } \\
\text { 者の } \\
\text { 個人 } \\
\text { 特性 }\end{array}$} & \multicolumn{3}{|c|}{\begin{tabular}{l|l} 
& 性別, 年齢, 視力矯正, 実験視力 \\
被験 & 本国での職業,帯在年数, 日本語力 \\
者の & 所有および主用交通手段,外出頻度 \\
属性 & 主に出かける場所 \\
& 景観への関心度などその他5項目
\end{tabular}} & 0 & $\begin{array}{l}0 \\
0 \\
0 \\
0\end{array}$ \\
\hline & 価值䈯 & & 12項目 4段階尺度 & 0 & 0 \\
\hline $\begin{array}{l}\text { 景観 } \\
\text { 評価 }\end{array}$ & $\begin{array}{l}\text { 満足 } \\
\text { 見る } \\
\text { S D 注 }\end{array}$ & 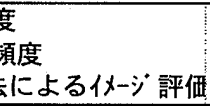 & $\begin{array}{r}\text { 1項目 } 5 \text { 段階尺度 } \\
1 \text { 項目 } 4 \text { 段階尺度 } \\
25 \text { 項目 } 7 \text { 段階尺度 }\end{array}$ & $\begin{array}{l}0 \\
0 \\
0\end{array}$ & $\begin{array}{l}0 \\
0 \\
0\end{array}$ \\
\hline
\end{tabular}

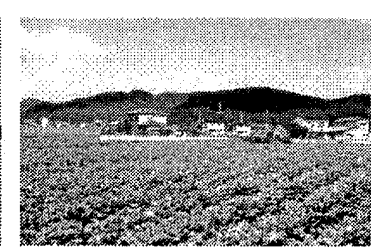

烟十新興住宅十山あり

表-3 回答票の内容

25項目 7 段階尺展
れている各要素の量や種類などを制限して構成した合成画像を用い た。呈示した景観スライドの例を写真 -1 に, 景観構成要素の操作 内容を表一 1 に示す。ここでは, 視点近くに平坦に広がる農地を近 景，農地に点在する住宅を中景，さらにその背後にある丘陵を遠景 之称し, 景観評価実験には, 近景 3 種, 中景 3 種, 遠景 2 種（以降, この 8 種類の要素を景観構成要素と称する) の全ての組み合わせに よって構成される 18 種類の景観に, ダミ一景観として 3 種類を加え た合計 21 種類の景観を用いた。なお, 本研究ではダミー景観を除き, 構成要素の組み合わせによる 18 種類の景観について検討を進める。

合成画像は，広島大学が所在する東広島市の一般的な農村景観を ベースとして作成した。東広島市は周辺を山々で囲まれた盆地地形 ではあるが, 広島県内ではまとまった農地の存在する地域であり， 区画整理された水田が広がるなかに，赤瓦の農家の点在する風景が 一般的である。したがって, 既往研究 ${ }^{23)}$ でも東広島市の代表的な景 観として使用した，近景を「整形な田」，中景を「伝統的な農家」， 遠景を「山あり」とする景観構成要素の組み合わせを基準として, 東広島市周辺で日常的に目に触れるかどうかという視覚体験の程度 を考慮して変化を持たせた。すなわち，近景では，平野部の大規模 農地には見られないが山間部や傾斜地では散見される未整備な「不 整形な田」, 東広島市にはほとんど存在しない「畑」を，中景では， 急速な都市化を象徵する「新興住宅」と, 島根県出雲平野に伝統的 に存在する築地松と呼ばれる「屋敷林」を，遠景では，広大な平野 部を想定し「山なし」をそれぞれ用意した。なお，各景観の構図が 大きく変わらないように, 遠景, 中景, 近景の占める部分をある程 度統一し，ある部分の要素の変化がなるべく他の部分の要素へ影響 しないよう留意した。

\section{2 実験方法}

実験期間は，日本人大学生（以降，日本人と称する）が 1998 年 11 月 12 月, 中国人留学生（以降, 中国人と称する）が 1999 年 12 月で, いずれも広島大学工学部 A2 棟 713 会議室で害施した。実験 状況を図-1 に示す。スライド映像で呈示した景観に対して，心理 的評価を求めるとともに眼球運動の測定を併せて行うため，機材の 制約から 1 回の実験における被験者数は 1 名である。測定に用いた アイカメラ（ナック社製 EMR－7）は，視野角で横方向 60 度, 縦方 向 40 度の範囲における, 被験者の視点(視線を向けている箇所の意, 
以降同じ）のXY座標值を出力するため, スライド映像の大きさが 被験者から見て横方向 30 度, 縦方向 20 度となるよう, スライドプ ロジェクタ, スクリーン, 被験者の位置などを決定した。

被験者数は, 日本人が 47 名, 中国人が 31 名であるが, 本研究ではそ のうち安定した測定結果の得られた各 30 名のデー夕を分析対象とする 注 2)。なお, 18 種類の景観全てを評価させることは, 被験者が疲労 するとともに，景観に対する慣れや飽きが生じ，また，実験者の意 図を推測させる可能性のあることから，被験者 1 人あたりの呈示景 観は, ダミ一景観 1 種類を含む 7 種類にとどめた注3)。ここで, 近景,

中景, 遠景の組み合わせによる 6 種類の景観については，実験計画 法に則り, 景観構成要素の内容が 1 人の被験者に対してそれぞれ偏 りなく呈示されるように留意した注 ${ }^{4)}$ 。したがって, 18 種類の景観 のうち, 異なる6種類ずつを各10名の被験者が評価したことになる。

日本人，中国人それぞれの実験手順を表一 2 に示す。実験にあた っての教示およびフェイスシートへの記入後の手順は若干異なる。 日本人の場合は, 被験者が実際に見ている箇所とアイカメラによる 測定点とがほぼ一致するよう調整するキャリブレーション作業を初 めに行い, 7 種類の景観ごとに 30 秒間, 自由に眺めさせると同時に 眼球運動を測定した後に, 再度 7 種類の景観を同一手順で呈示して 心理的評価を求めている。一方, 中国人の場合は, 心理的評価と注 視特性との対応関係をより明確にすることを意図して, キャリブレ ーション作業, 30 秒間の眼球運動の測定, その直後にスライドの映 写を停め心理的評価を求めるという手順を，7種類の景観ごとに繰 り返す方法に改めた。また, 各景観の呈示前後に無地スライドを呈 示し, 2 3 秒間, スライドの四隅を凝視させ, その際の座標值をア イカメラから直接出力される座標值を修正するための補正值とした。

実験に用いた回答票の質問項目を表－3 に示す。フェイスシート には被験者の属性, 価值観のほか, 東広島市の一般的な農村景観の バリエーションとなる景観を評価対象とすることから, 地域に対す る印象や接触程度, 農業に対する関心や経験などの項目を加えてい る。各景観に対する評価では, 総体的評価としての「満足度」, SD 法によるイメージ評価 25 形容詞対のほか, 呈示したスライドに類す る景観を日常的に眺める機会が多いかどうか, 視覚体験の程度を尋 ねる「見る頻度」を加えている。

\section{3 眼球運動データの解析方法}

人間が対象物を観察する際には, 眼球運動を抑制し, ある程度の 時間ある範囲のなかに視点をとどめて情報を得ており，このような
状態を注視と称する。注視点の基準としては, 中心䆟の大きさなど ある範囲の視角を定め, その範囲内に入った動きを 1 つの注視点と 定める方式がよく用いられている。本研究では, 筆者らのこれまで の研究成果から ${ }^{27,28)}$, 画角にして半径 1.5 度末満の円形範囲内に, 0.2 秒以上留まった場合を注視点として定義する注5)。

サンプリング間隔 $1 / 30$ 秒でアイカメラより出力された座標デー 夕の変換過程について, 図一2にしたがって述べる。（a）は補正以 前の30秒間 900 フレームの座標データによって描いた視点の軌跡で ある。これに無地スライドの四隅に対する座標值を補正值として用 い, 二次元射影変換を施した後の軌跡が（b）である。景観呈示の 前後それぞれの補正值によって 2 種類の変換結果が得られるが, 構 成要素の位置などとの対応から，実態をより正確に反映していると 考えられるいずれか一方を採用する。さらに，分析範国外のデータ を不正データとして除外し（c）を得る。ただし，分析対象範囲と しては, スライド映像外縁付近の注視も想定されることから, 横 30 度 $\times$ 縦 20 度のスライド映像の領域から上下左右に各 1.5 度外側まで, すなわち, 横 33 度 $\times$ 縦 23 度の範囲とした。最後に, 前述の定義に 基づいて注視点を決定する。注視点による軌跡を（d）に示す。本 研究はこの最終的に得られた注視点データをもとに考察を進める。

\section{4 被験者の属性}

被験者は, 日本人, 中国人ともに広島大学に在籍する学生である。 日本人は建築学専攻の学部 2,3 回生 (2 回生は 4 名の夕) で年齢は 20 22 歳, 約 8 割が男性である。中国人は主に工学部に在籍してお り, 年齢 $22 \sim 42$ 歳で, 大学院在籍が多いために 25 歳〜30 歳が約半 数を占め, 性別は日本人と同様に男性が 7 割となっている。

次に, フェイスシートの質問項目に対する回答結果について述べ る。日本人，中国人の出身地に関する回答構成を図-3 に示す。中 国人は華東，東北地方出身者が多く，ウイグルやチベット等の少数 民族地区は皆無であり，全体の約 $2 / 3$ が人口 100 万以上の大都市出 身である。日本人は近畿地方出身が多く, 次いで中国地方であるが, 東広島市や島根県出身の者は皆無であり, 全体の約 1/3 が郡部の出 身で, 政令指定都市出身者は 5 名と少ない。したがって, 日本人よ り中国人の方が都市的環境の体験がやや豊富であるといえる。東広 島市と比べて自分の出身地をより都市的であると評価する者の割合 が中国人で高いことや，中国人の方が農業に対する関心は高いもの の農作業の経験で劣ること（日本人: $50 \%$, 中国人: $37 \%$ ) などは, この結果と関連するものと思われる。

また，東広島市における居住経験では，日本人の 9 割が $2 \sim 3$ 年
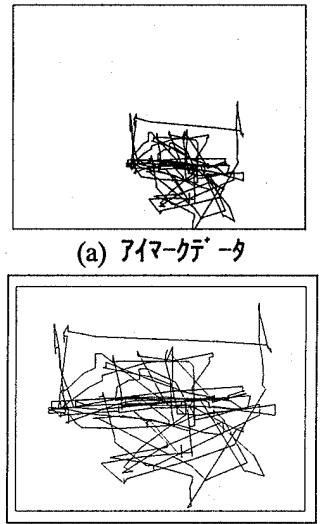

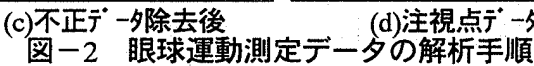

(a) $31 \nabla-\eta \bar{T}^{*}-タ$

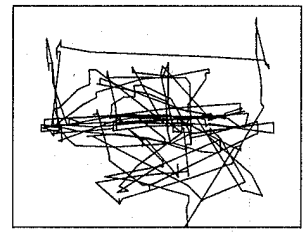

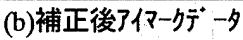

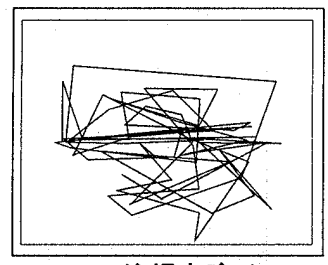

d)注視点 $\ddot{J}^{*}-9$

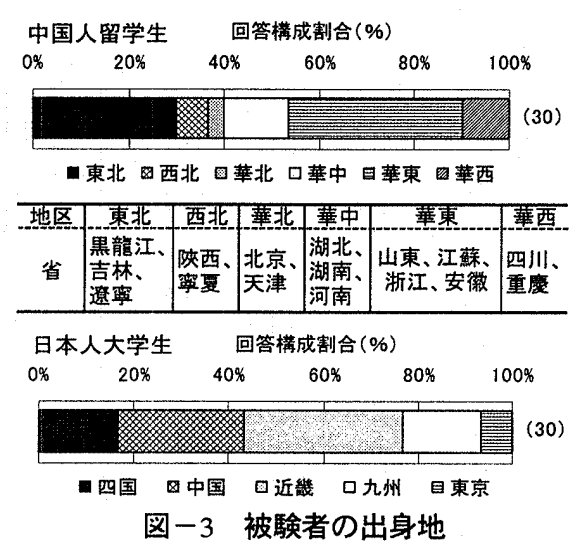

であるのに対し，中国人は 2 年以上が 5 割弱を占め, やや経験に乏しいと考 えられる。なお, 外出の頻度や, 景観 に対する関心度は日本人，中国人とも に高く，共通した傾向が得られた注6)

\section{3. みどり景観に対する心理的評価 \\ 3. 1 景観を見る頻度}

呈示した景観を「見る頻度」につい ての 4段階尺度の回答に 1 4の得点を 付与し求めた平均評価得点を, 日本人, 中国人それぞれについて図一 4 に示す。 
これより，日本人，中国人に共通した傾向として，近景が「不整 形な田」や「畑」の場合に比べ「整形な田」の景観が高頻度となり， 中景では「伝統的な家」の場合に頻度が高く, 次いで「新興住宅」 の景観となり，「屋敷林」の場合にはほとんどの景観で著しく低頻度 となっていることがわかる。日本人，中国人いずれの被験者も東広 島市に在住していることから，「整形な田」や「伝統的な家」など東 広島市において一般によく見かける構成要素を含む景観を高頻度と する共通した傾向が得られたものと考えられる。

なお，全般に中国人のほうが高頻度側の回答となっており，「屋 敷林」のある景観において特に差が大きいこと，その一方で，東広 島市の標準的な農村景観である「整形な田」と「伝統的な家」に「山 あり」を組み合わせた景観においては，逆に日本人のほうが高頻度 となっていることなどから，地域に対する視覚体験が中国人よりや や豊富で，日本の他地域の状況に関する知識も多い日本人は，いず れの要素も日本的であることを認識しつつ, 現在居住している地域 での視覚体験を基準にして，各構成要素の内容の差異を明確に把握 し, 細かく峻別して判断していることが予想される。これに対して, 中国人被験者は日本における居住経験が日本人より浅く, 判断に出 身国における視覚体験も多分に影響している可能性が予想される。 すなわち, 呈示した景観構成要素がいずれも日本で収集されており, 中国本国ではあまり見かけない要素であるため, 来日前に比べて来 日後の現在の生活においては「見る頻度」を全般に高く回答したも のと考えられる。

\section{2 景観のイメージ評価構造と評価傾向}

筆者らの既往の研究 ${ }^{23)}$, 24) で, 景観のイメージ評 価においては，出身国の異なるグループ間でもほぼ 共通した因子構造が得られていること, 本研究でも, 日本人，中国人それぞれで分析を行った結果，ほぼ 共通した因子構造が得られたことから，ここでは両 被験者群の統合デー夕に対して因子分析を適用した 結果のみを示し，共通の因子構造に基づく平均因子 得点による比較を行う。S D法による 25 形容詞対に ついて, 両被験者群の統合デー夕を対象に主因子 法・バリマックス回転による因子分析を適用し，固 有值 1.0 以上の 4 因子を抽出した結果を表一4に示す。 これより，第I因子は「不快な一快適な」「好きな 一嫌いな」などの因子負荷量が高いことから，総体 的な評価を示す『快適性』として解釈される。同様 に，第I因子は「伝統的な一革新的な」「新しい一古 い」どの形容詞対の因子負荷量が高いことから『伝 統性』と解釈でき，第血因子は「雑然とした一整然 とした」などから『整然性』，第IV因子は「活発な一 おとなしい」「特徵のある一平凡な」などから『特異 性』とそれぞれ解釈できる。

得られた 4 因子について，日本人，中国人ごとに 各景観構成要素の平均因子得点を求め, 二次元平面 上に布置した結果を図一5 に示す。なお，ここでは 近景・中景・遠景のそれぞれについて，同一の内容 を有する複数の景観をまとめて算出している注7)。

『快適性』では，日本人，中国人いずれも，正側
の低い評価に中景が「屋敷林」の景観が布置されるのに対し, 負側の 高い評価に中景が「伝統的な家」新興住宅」の景観が布置されている。 ただし, 中国人では,「新興住宅」と「伝統的な家」がほぼ同程度の高 い評価となっているが, 日本人の場合は, 「新興住宅」の中庸な評価 と比べ，「伝統的な家」が中国人より著しく高く評価されている。中 国人は本国ではあまり見られない工業化住宅様の「新興住宅」につ いて，「伝統的な家」と同様に日本独特の住宅と認識しており，いず れも異国的と判断されることから高く評価されたものと考えられる。 また, 中国人と比べて日本人の場合, 中景の要素の変化については 評価の差が著しいが, 近景, 遠景の要素の変化については評価の差 がそしく, 中景の内容によって評価傾向の多くが左右されているこ とがわかる。

『伝統性』では中景の構成要素の違いによって評価に大きな差が みられ，日本人では「伝統的な家」「屋敷林」「新興住宅」の順に『伝統 性』が低くなっている。日本人は, 特に居住地域である東広島市を 基準として日本的な事物に対する明確な判断基準を有すると考えら れる。一方，中国人でも同様の順序で『伝統性』は低くなるが，日 本人ほど「伝統的な家」と「新興住宅」の評価に大きな差はみられない。 また，「屋敷林」の評価が「伝統的な家」とほぼ同程度になっている ことなどから, 中国人の場合は日本的か否かという観点と, 歴史的 か否かという観点の双方が判断の基準となったため『伝統性』の評 価がやや曖昧になったものと考えられる。

『整然性』においては，「新興住宅」「畑」「屋敷林」についての考
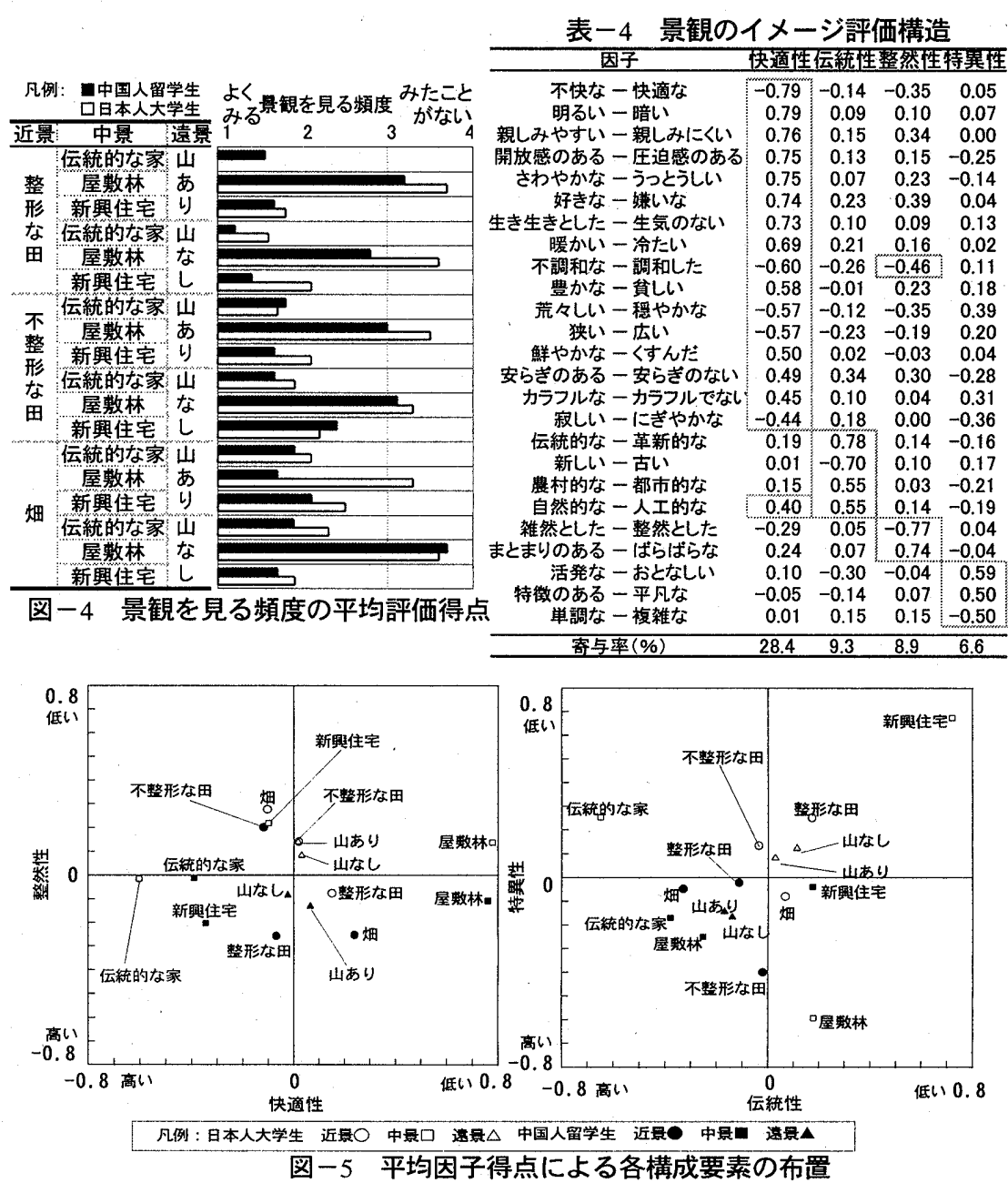
え方に両被験者群で大きな差異がみられる。すなわち, 中国人が整 形な田」や「畑」といった景観全体に均質に広がる農地,あるいは色や 建物の様式が共通している「新興住宅」「屋敷林」に対して，「整形 な田」と同程度に整然とした印象を持つのに対し，日本人は「整形 な田」以外の要素をいずれも雑然としたものとして捉えている。

『特異性』は『伝統性』と同様に，日本人の場合は中景の変化に よる評価の差異が大きいが，中国人ではそれほど大きな差異はみら れない。また，日本人が東広島市ではみられない中景の[屋敷林」を 最も特徵的な要素として捉えているのに対し，中国人では「屋敷林」 より近景の「不整形な田」を特徵的と捉えており，地域に対する知識 の過多による影響が認められる。すなわち，「屋敷林」として示した 築地松の形状は，東広島市で全くみられないだけでなく全国的にも 珍しいものであり，日本人は東広島市を基準とするだけでなく，こ れまでの日本における視覚体験の全てを通して，その特異性を判断 しているのに対し，中国人は，いずれの要素も日本的と捉えてはい るものの「屋敷林」の特異性を日本人ほど明確には判断できないも のと考えられる。

以上のように，「新興住宅」「屋敷林」「畑」など，東広島市ではあ まり見られないあるいは一般的ではない構成要素に対して, 日本人, 中国人それぞれのイメージ評価傾向で差異がみられ，これまでの視 覚体験が異なることによって評価の判断基準も異なり，主として中 景に着目する日本人の明膫な判断基準と比べ，日本での経験の不足 や本国での過去の経験の奇与などによって，中国人の判断基準は曖 昧になり，個人による捉え方の差も大となることが示晙される。

\section{4. みどり景観に対する注視特性}

本章では, 中国人，日本人における眼球運動の測定結果から注視 点を求め，両被験者群の注視特性について比較を行う。

4. 1 景観における注視点の分布と注視点数

はじめに，呈示した景観のどの部分に注視点が集中するのかを概 括するために, 被験者からみて横 33 度 $\times$ 縦 23 度の分析対象範囲を 1 度刻みに分割し，得られた 759 の正方小領域ごとに各景観の 30 秒 間の注視点数を, 被験者 10 名の累積值として算出した。写真一 1 で 呈示景観の例として挙げた景観画像について, 注視点の平面的な分 布傾向を中国人，日本人それぞれ図一 6 に示す。また，注視点の分 布についてより定量的に把握するため, 景観構成要素ごとに, 内容 を同じくする複数の景観について, 30 秒間で得られた注視点の座標 値からX方向 (水平方向), Y方向（垂直方向）の標準偏差をそれぞ

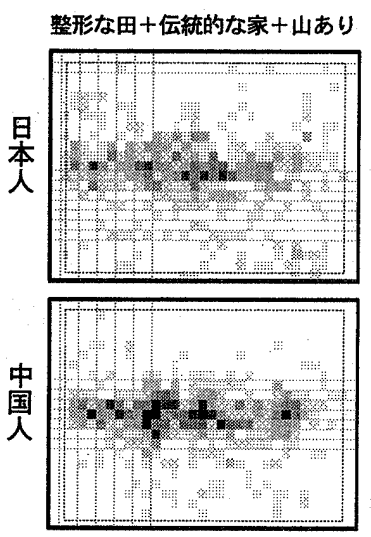

図-6

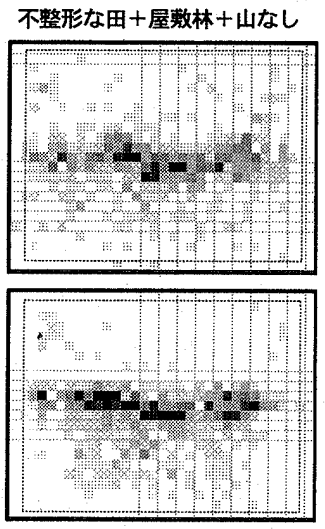

姆十新興住宅十山あり

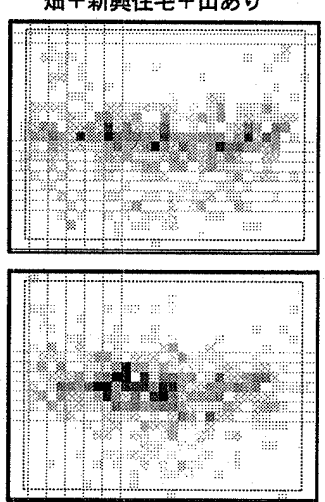

洁视
れ求めた。結果を図ー7に示す。

これより，中国人，日本人に共通する全体的な傾向として，いず れの景観においても，垂直方向に関しては中央の中景部分がよく注 視され, 次いで中央より下部の近景がみられ, 中央より上部の遠景 ではあまり注視が生起していないことがわかる。また，X，Y方向 の標準偏差の結果をみると, 全体的には日本人より中国人の方がX 方向, Y方向ともに標準偏差が小となり, 注視点が景観の中央付近 に集中する傾向が認められる。各構成要素の内容別による標準偏差 の多少は，X方向では中国人，日本人とも共通しており，近景では 「不整形な田」で小，中景では「新興住宅」で大，遠景では「山な し」で大となっている。このうち，「不整形な田」は中央にある畔に 視線が集中し，左右へ分散しないものと考えられる。対照的に「新 興住宅」は，形状が異なる住宅が景観の左右端の間に散在し，注視 点の分布が水平方向へ広がったものと予想される。また,「山なし」 の場合, 中景がスカイラインを形成することになり, 中景の内容の 相違や事物の配置がより明瞭に捉えられるため, 注視点が左右に散 らばったものと考えられる。Y方向については，近景と中景で日本 人と中国人に多少の差異が認められる。近景では, 複雑な様相の「畑」 の標準偏差が最も大であることは共通するが，中国人では「不整形 な田」，日本人では「整形な田」がそれに次いでいる。また，中景で は,「伝統的な家」「屋敷林」「新興住宅」の順に標準偏差が増大寸る 中国人の結果に対して，日本人では全く逆の傾向がみられる。

次に, 各景観における具体的によく見られる要素が何かを検討す るため, 近景, 中景, 遠景のいずれの部分に該当するかによって注 視点を区分し, 各景観について, それぞれの構成要素ごとに 30 秒間 の注視点数を算出した注 ${ }^{81,9 \%}$ 。構成要素の内容によって複数の景観の 平均値を求めた結果を図一 8 に示す。

まず, 近景, 中景においては, 中国人の注視点数が全体的に多く,

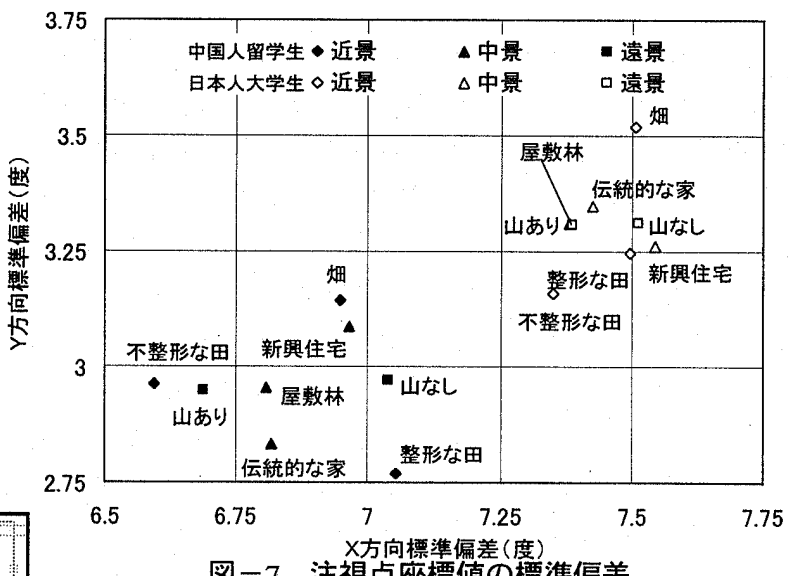

図-7 注視点座標值の標準偏差

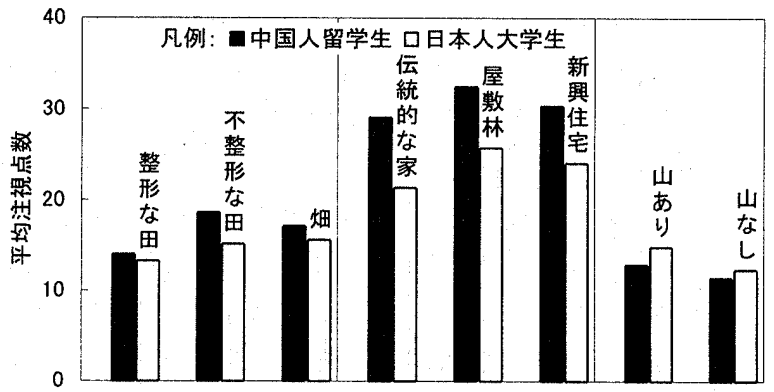

図 -8 景観構成要素の内容別注視点数 


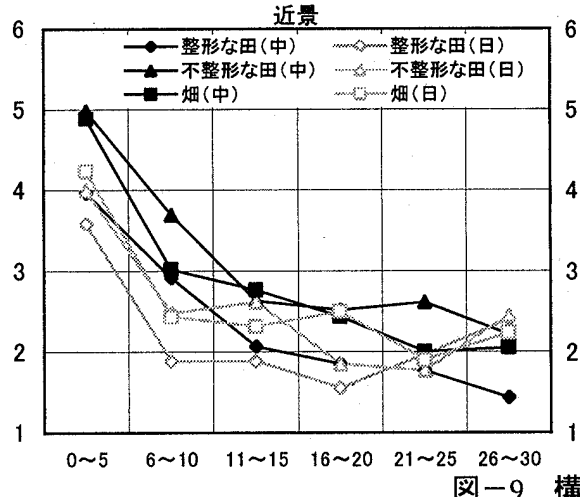

図-9

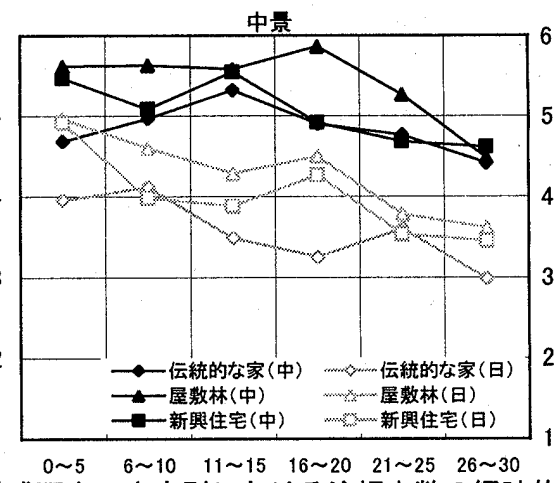

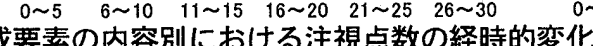

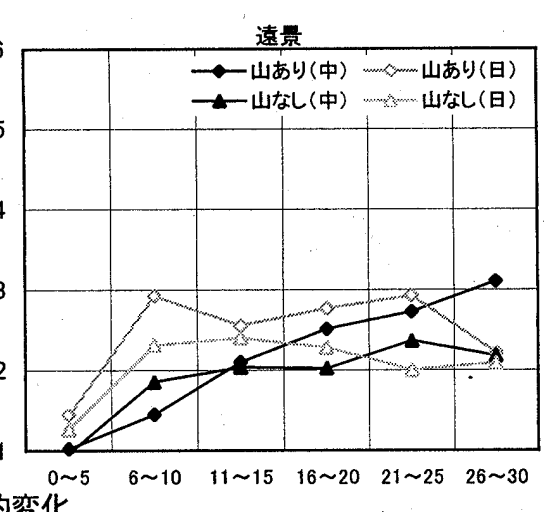

中景でも次第に注視点数は減少するが，その变化は緩慢であり，近 景のような極端な低下は認められない。遠景は中景，近景と異なり 呈示直後の注視点数は少ないが徐々に増加している。すなわち, 景 観の呈示直後は主に近景，中景が注視されるが，近景はすぐに見ら れなくなり，代わって遠景に視線を向けるようになるといえ，景観 に対する注視特性は経時的変化の観点からも，日本人，中国人でほ ぼ共通することがわかる非10。

さらに, 要素の内容ごとに仔細に検討するなら, 前節では, 近景 で「整形な田」の注視点数が日本人, 中国人ともに少なく, また, 中国人では「不整形な田」が，日本人では「不整形な田」と「畑」 がそれぞれよく注視される傾向のあることを示したが，多少の例外 はあるものの, 5 秒単位の 6 区分のほとんどで同様の傾向がみられ， 経時的な変化は認められない。中景の「屋敷林」と「伝統的な家」， 遠景の「山あり」と「山なし」においても同様に，30秒間の呈示時 間全体で得られた傾向が各時間区分でほぼ一貫して維持されており， これらの結果から, 日常的に目に触れる事物に比して, 視覚的経験 の乏しい事物を注視する傾向が，少なくとも 30 秒間の呈示時間中は 継続することが予想される。このことは，見慣れない事物に対する 情報収集のための観察や興味あるいは関心が，見慣れた事物に対す るそれと同程度にまで容易には低下しないことを意味する。

\section{5. 注視特性と心理的評価との関連性}

本章では，これまで述べた結果より，地域景観に対する注視特性 と心理的評価との関連性について総合的に考察し, 景観の認識・評 価プロセスの態様について，出身国による影響を検証する。

近景, 中景, 遠景の各構成要素について, 心理的評価並びに注視 点数について被験者ごとに平均值を求め, 日本人，中国人それぞれ 30 サンプルに対する相関倸数を算出した。心理的評価としては, 統 合デー夕による因子分析で得られたイメージ評価 4 因子を，注視特 性としては, 各景観に対する注視点数を用いた。結果を表 -5 に示 す。ここで，相関係数の值が高いということは，ある要素に対する 注視点が多ければ多いほど, ある評価が向上する（あるいは低下す る）ことを意味し，その要素を着目するか見過ごすかによって，そ の要素を含む景観全体の評価が左右されることを示す。注視特性は 視覚的刺激に対する生理的反応であるとも言え，前章で述べたよう に, 構成要素の内容や日本人, 中国人の相違によらず比較的共通し た傾向を示すことから，ここでも全般にあまり高い相関は得られて いないが，以下では，同表に示した相関係数の有意確率より, 有意 性が高い関連を取り上げ, 日本人と中国人の異同について検討する。 


\begin{tabular}{|c|c|c|c|c|c|c|c|c|c|}
\hline & \multirow{2}{*}{ 注視点数 } & \multicolumn{4}{|c|}{ 中国人留堂生 } & \multicolumn{4}{|c|}{ 旦本人大学生 } \\
\hline & & 快適性 & 伝統性 & 整然性 & 特異性 & 佒適性 & 伝統性 & 整然性 & 特異性 \\
\hline \multirow{3}{*}{$\begin{array}{l}\text { 近 } \\
\text { 最 }\end{array}$} & 整形な田 & $\begin{array}{c}0.03 \\
(0.88)\end{array}$ & $\begin{array}{c}0.06 \\
(0.74)\end{array}$ & $\begin{array}{c}0.16 \\
(0.39)\end{array}$ & $\begin{array}{c}-0.14 \\
(0.46)\end{array}$ & $\begin{array}{c}0.04 \\
(0.82)\end{array}$ & $\begin{array}{c}-0.13 \\
(0.51)\end{array}$ & $\begin{array}{c}-0.18 \\
(0.35)\end{array}$ & $\begin{array}{c}-0.01 \\
(0.97)\end{array}$ \\
\hline & 不整形な田 & $\begin{array}{c}0.23 \\
(0.21)\end{array}$ & $\begin{array}{c}0.25 \\
(0.18)\end{array}$ & $\begin{array}{c}-0.16 \\
(0.41)\end{array}$ & $\begin{array}{c}0.16 \\
(0.41)\end{array}$ & $\begin{array}{c}0.02 \\
(0.91)\end{array}$ & $\begin{array}{l}0.27 \\
(0.15)\end{array}$ & $\begin{array}{c}0.12 \\
(0.52)\end{array}$ & $\begin{array}{c}0.00 \\
(0.98)\end{array}$ \\
\hline & 㚼 & $\begin{array}{c}0.05 \\
(0.80)\end{array}$ & $\begin{array}{l}0.36 \\
(0.05)\end{array}$ & $\begin{array}{c}0.07 \\
(0.71)\end{array}$ & $\frac{0.22}{(0.24)}$ & $\begin{array}{c}-0.10 \\
(0.60)\end{array}$ & $\begin{array}{l}0.29 \\
(0,12)\end{array}$ & $\begin{array}{c}-0.18 \\
(0.35)\end{array}$ & $\begin{array}{c}-0.26 \\
(0.16)\end{array}$ \\
\hline \multirow{3}{*}{$\begin{array}{l}\text { 中 } \\
\text { 皁 }\end{array}$} & 伝統的な家 & $\begin{array}{c}0.27 \\
(0.16)\end{array}$ & $\begin{array}{c}-0.13 \\
(0.51)\end{array}$ & $\begin{array}{c}-0.26 \\
(0.17)\end{array}$ & $\begin{array}{c}0.10 \\
(0.61) \\
\end{array}$ & $\begin{array}{c}-0.17 \\
(0.36)\end{array}$ & $\begin{array}{c}-0.12 \\
(0.52)\end{array}$ & $\begin{array}{c}0.11 \\
(0.57)\end{array}$ & $\begin{array}{c}0.08 \\
(0.67)\end{array}$ \\
\hline & 屋数林 & $\begin{array}{c}0.13 \\
(0.50)\end{array}$ & $\begin{array}{c}-0.32 \\
(0.09)\end{array}$ & $\begin{array}{c}0.25 \\
(0.19)\end{array}$ & $\begin{array}{c}0.01 \\
(0.95)\end{array}$ & $\begin{array}{c}0.13 \\
(0.48)\end{array}$ & $\begin{array}{c}-0.10 \\
(0.61)\end{array}$ & $\begin{array}{c}-0.43 \\
(0.02)\end{array}$ & $\begin{array}{c}-0.05 \\
(0.81)\end{array}$ \\
\hline & 新興住宅 & $\begin{array}{c}-0.26 \\
(0.17) \\
\end{array}$ & $\begin{array}{c}-0.23 \\
(0.24) \\
\end{array}$ & $\begin{array}{r}-0.43 \\
(0.02) \\
\end{array}$ & $\begin{array}{c}-0.24 \\
(0.21) \\
\end{array}$ & $\begin{array}{c}0.26 \\
(0.16) \\
\end{array}$ & $\begin{array}{l}0.38 \\
(0.04) \\
\end{array}$ & $\begin{array}{r}0.24 \\
(0.20) \\
\end{array}$ & $\begin{array}{c}0.39 \\
(0.03) \\
\end{array}$ \\
\hline \multirow{2}{*}{$\begin{array}{l}\text { 逵 } \\
\text { 最 }\end{array}$} & あり & $\begin{array}{c}-0.06 \\
(0.74)\end{array}$ & $\begin{array}{c}-0.18 \\
(0.34)\end{array}$ & $\begin{array}{c}0.13 \\
(0.48)\end{array}$ & $\begin{array}{c}-0.04 \\
(0.85)\end{array}$ & $\begin{array}{c}0.16 \\
(0.41)\end{array}$ & $\begin{array}{r}0.36 \\
(0.05)\end{array}$ & $\begin{array}{r}0.07 \\
(0.73)\end{array}$ & $\begin{array}{c}0.26 \\
(0.17)\end{array}$ \\
\hline & 山なし & $\begin{array}{r}-0.17 \\
(0.37) \\
\end{array}$ & $\begin{array}{c}0.02 \\
(0.92) \\
\end{array}$ & $\begin{array}{c}-0.10 \\
(0.60) \\
\end{array}$ & $\begin{array}{c}-0.23 \\
(0.22) \\
\end{array}$ & $\begin{array}{r}0.14 \\
(0.46) \\
\end{array}$ & $\begin{array}{r}0.18 \\
(0.35)\end{array}$ & $\begin{array}{c}0.02 \\
(0.91)\end{array}$ & $\begin{array}{c}0.07 \\
(0.71)\end{array}$ \\
\hline
\end{tabular}

近景では,「畑」や「不整形な田」と比較して, 東広島市で一般的 によく見受けられる「整形な田」では, 両被験者群ともいずれの因 子についても相関がみられない。すなわち, 要素の形状や分布が整 然として変化がなく, 現在の居住地域の景観構成要素として見慣 れていることから, あまり強く認識されず, 注視点の多少が心理 的評価と特に関連しなかったものと考えられる。

中景では, 中国人の場合, 『伝統性』『整然性』で, 日本人の場合 は『整然性』で，それぞれ「屋敷林」との相関がみられる。前述し たイメージ評価の結果では, 中国人は「屋敷林」を「伝統的な家」 とほぼ同程度の『伝統性』であると評価しており，あまり着目しな い（注視点数の少ない）被験者は単純に日本独特の事物であると認 識するが，よく観察する被験者は「屋敷林」の特徴的な形状に気づ き, そのような認識が低下するものと思われる。また，「屋敷林」に あまり着目しない日本人被験者は, その輪郭の明瞭さや，遠景に山 がある場合にはそれと一体的に捉えることなどによって，単純な印 象を抱くが, 複雑なテクスチュアに関心を向ける場合は, よく観察 する可能性が指摘できることから，『整然性』との関連は解釈しうる。

「新興住宅」については，中国人では『整然性』を筆頭にいずれ の因子でも負の相関が，日本人では『伝統性』『特異性』を筆頭にい ずれの因子でも正の相関がそれぞれみられる。日本人は，『伝統性』 『特異性』で「新興住宅」を著しく低く評価していることから，あ まり観察しない場合は「伝統的な家」との対照性が強く意識され， 低評価となるのに対し，よく観察する場合には，日本的な特徴的な 部分が発見され，評価も多少なり向上するものと推測される。

これに対して，中国人は，『整然性』では「伝統的な家」より「新 興住宅」の評価が高く、『快適性』でも「伝統的な家」とほぼ同程度 の評価となっている。したがって，あまり観察しない場合は，新し い日本的な住宅を単純に高く評価するものの, 上く観察する場合に は, 日本人と同様に周辺環境との不調和や，形状や配置の不統一な ども意識され, 評価が低下するものと考えられる。これらの結果は,

「新興住宅」を日本人が否定的，中国人が肯定的にとらえる全体的 な評価傾向が，それらの要素をあまり観察しない被験者においては 直接的に現れるのに対して，よく観察される場合には減衰する可能 性の存在を示唆しているといえる。

遠景では，日本人の場合，「山あり」で『伝統性』と多少の相関 が認められるが, 中国人の場合, 全般に相関はみられない。前述し た構成要素別の注視点数では, 日本人は遠景の注視点数が多く, 特 に「山あり」で顕著であることから, むしろ中景との組み合わせに
おいて注視点数が増減し，心理的評価との関連がみられたものと考 えられる。

以上の結果から，「整形な田」「伝統的な家」のように東広島市の 地域景観として一般によく見られる, 被験者の視覚体験が豊富で,

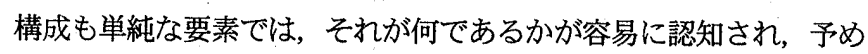
被験者が有する情報によって評価が決定されるため, 中国人, 日本 人とも共通して, 注視特性と心理的評価との関連性が低くなるもの と推測される。

これに対して，「屋敷林」や「新興住宅」などのように，被験者 の視覚体験が劣り, 要素に対する認識や知識の程度に社会・文化的 背景による差異がある場合は, それら要素に対する観察の程度によ つて得られる情報も異なってくることが予想され，心理的評価と注 視特性との間に多少なり関連が生じるものと考えられ，そこには出 身国による相違も現れるものと考えられる。

\section{6. 結語}

本研究は, 評価者の社会・文化的背景が景観評価に及ぼす影響を 明らかにすることを意図し, 社会・文化的背景に加えて物理的環境 条件の全く異なる出身国の被験者に対して, アイカメラによる眼球 運動の計測を含む心理的評価実験を実施し, 景観の認知・評価プロ セスにおける出身国の相違について検討を行った。得られた知見を まとめて以下に示す。

1）はじめに, 呈示した地域景観に対する認識の程度の比較から, 地域に対する視覚体験並びに情報が豊富な日本人被験者は, 各構 成要素の内容の差異を明確に認識しているのに対し, 中国人被験 者は日本での居住経験が浅く, 本国での視覚体験による影響も受 けるため, 判断基準が複雑になる可能性が示唆された。

2) 景観のイメージ評価 25 形容詞対について, 両被験者群の統合デ 一夕に因子分析を適用し, 『快適性』『伝統性』『整然性』『特異 性』の 4 因子を抽出した。また, 各構成要素の平均因子得点を国 別に算出し, 評価傾向を検討した結果, 構成要素の内容によって 両被験者群の評価傾向は異なり, 特に日常的に見られない「屋敷 林」や「畑」,「新興住宅」などで, 視覚体験や文化的背景の違い によって差異の大きいこと, 日本人被験者の多くが主に中景の要 素を基準として，評価・判断を行っていることなどを把握した。

3）景観に対する注視特性として, 注視点の分布と注視点数を国別 に求めた結果から, 日常的によく目に触れる事物は見慣れている ために見過ごし, 視覚体験の少ない事物に対しては, それが何で あるかを探索し，情報を収集するために視線を向ける傾向が，日 本人，中国人に共通した傾向として認められた。

4) さらに, 注視特性の時系列的な変化においても, 呈示直後は近 景と中景がよく注視されるが, 時間経過に伴い注視点数が低下し, 特に近景で著しいのに対して，次第に遠景へ視線が向けられるよ うになることや，見慣れない要素が注視され，見慣れた要素が注 視されない傾向が呈示時間中継続することなどが，日本人，中国 人のいずれでも認められることを示し，経時的変化の観点からも 注視特性がほぼ共通することを把握した。

5) 最後に, 認知・評価プロセスの総合的考察として, 景観のイメ ージ評価より抽出された 4 因子と注視点数との相関を構成要素別, 国別に求めた。その結果, 日常的によく見慣れた要素に対しては, 
両被験者群ともに注視点数と心理的評価との間に相関はみられ ないことを示した。また, 見慣れない要素に対しては, 視覚体験 や，その要素に対する認識や知識の程度などによって得られる情 報が異なるため, 注視の程度が心理的評洒と関連する場合があり， そこに出身国による相違の現れる可能性のあることを示した。

以上の結果から, 評価者の社会・文化的背景や生育環境の物理的 条件の違いが心理的評価に及ぼす影響を，注視特性の援用によって 詳細に把握する可能性が示唆されたと言える。

しかしながら, 本研究では実験構成上, 近景, 中景, 遠景の景観 構成要素ごとに分析を行っているため, 要素の組み合わせによる調 和性や統一性などについては充分な検討を行っていない。したがっ $\tau$, 今後, 多様な構成要素を含む一般的な景観について, 注視特性 と心理的評価との関連性に評価者の社会・文化的背景がどのように 影響を与えるか, 新たな実験を加えて検討する必要がある。

また，注視特性の把握にあたつても，積極的に情報収集している 場合と単純に視線を向けている場合の注視点の峻別や，眼球運動の 測定と心理的評価との時間差の解消など，本研究の成果をふまえた 上で，さらなる検討を要する事項も多く，実験計画を策定する際に は，これら諸点に対する配慮も必要と考えられる。

\section{【謝辞】}

本研究の一部は, 平成 10 年度文部省科学研究費補助金 $\mathrm{C}(2)$ (代表 : 西 名大作)によったことを記す。また，実験にご協力して頂いた広島大学の 大学生および中国人留学生の方々に謝意を表する。

\section{【注】}

1) 本論文は参考文献 299，30)をもとに加筆・再編したものである。

2) 被験者のうち, 眼鏡使用者やコンタクトレンズ装用者などの中には, 視点座 標值の視野範用外への冕脱や，2つの座標值間での反復運動などが発生した 者が㧍り，そのようなデー夕の得られた被験者については分析から除外した。 なお，中国人被験者の場合は，実験の最初に眼球運動測定の適否を判断した ために除外した被験者は少なくなっている。

3）ダミ一景観は，実験者の意図を被験者になるべく意識させないため用いた。

4) 18 種類の景観全てを用いる, 被験者をブロックとしたいわゆる乱塊法によ る実験計画は適切ではないと判断し，ラテン方格配置に基づいて各6 種類の 呈示景観の組み合わせ 3 組を選定した。すなわち，いずれの6 種類の景観に も，近景 3 種類，中景 3 種類，遠景 2 種頑が均等に含まれ，また，近景 $\times$ 遠 景, 中景×遠景による6 種類の組み合わせの全てが含まれている。ただし， 近景×中景の 9 種類については，そのうちの6 種類しか含まれない。

5) 既往研究では,アイカメラから出力される連続的な視点座標值の処理にあた って，一定時間間隔でデー夕を区分する方法や，視点の移動速度がある值以 下の場合に注視していると判断する力法など、多くの提案がなされているが， 本研究では, 視点が一定時間以上，一定の円形範囲内に停留した時に，この 範囲の中心座標を注視した点（以降，注視点）とする方法を採用する。

6）実験条件をなるべく統制するよう努力したにもかかわらず，日本人，中国人 被験者には、ここに挙げたような差異が多少なり存在する。したがって, 本 研究の成果は, 日本人之中国人の出身国の違いによる一般的な傾句を厳密に は意味しないが, 既往の研究成果をふまえ, 他の解釈可能性を考慮した上で, 出身国の違いがより明確になるように以降の考察を行つている。

7）近景, 中景, 遠景の要素の組み合わせによって, それぞれ独自の景観が構成 されていることを考えれば，本来，18 種類の景観について評価傾向を検討す ベきである。しかしながら，本実験では，各被験者が18 種類の景観のうち 6 種類しか評定していないため，各景観ごとに評価傾向を仔細に検討するには サンプル数に問題があること，また，近景，中景，遠景を要因とした三要因 の分散分析を適用した結果，二次，三次の交互作用にほとんど有意性が認め られなかったことなどから，ここでは個々の景観ではなく，主に要素の内容 に従って検討を進めた。

8）近景, 中景, 遠景の注視点数は, 横 33 度×縦 23 度の 739 正方小領域加ら景 観外の部分を含む縁辺の 88 小領域を除いた 651 小領域について，小領域ごと の注視点数を, 各小領域の該当する影観構成要素にしたがって積算した。な お, 中景, 遠景に該当する小領域数は, 要素の内容によって多少異なるが, ここでは要素の面積割合による注視点数の基準化なごの操作は施していない。 これには，面積の大きい近景や遠景の注視点数が少なく，面積の小さい中景 で注視点数が多いことから，面積の大小が注視点数の多少に必ずしも対応し ておらず, むしろ要素の内容による可能牲があること，基準化によって要素 間の差異がより顕著になることがあることなどを考虑した。

9）注視点は，ある限定された範冊への視点の滞留を意味するにすぎず，能動的
に情報収集を行っていない場合にも，開眼していれば観測されうる。したが って，厳密には積極的，意識的な注視の終了時点までを分析対象簌用とすべ きであるが，終了時点の判断や，意識的な注視か研かの判断は現状では困難 であることから，注視点数に基づく以降の分析においては，全て測定時間の 30 秒間における集計值を用いる。

10)30秒間の測定時間後半における遠景の注視点数の増加は, 近景や中景に代え て遠景を意識的に眺めるようになつたとも解釈できるが，認知・評価プロセ スが終了し，単純に視線を向けているにすぎない可能性も存在する。

\section{【参考文献】}

1) 鈴木 誠, 田崎和裕, 進士五十八: 外国人の日本庭園観に関する比較研究, 造園 雑誌, Vol. 52, No. 5, pp. 25-30, 1989

2）杉尾邦江:ニュージーランド人と日本人の住宅庭園景観に対する意識に関する比 較研究，造園雑誌，Vol. 54, No. 5, pp. 227-232, 1991

3）岡島達雄, 金 東永, 簏 和義, 内藤 昌: 白本・韓国伝統建築空間のイメージ 評定尺度抽出 日本・韓国伝統建築空間のイメージ特性（その1），日本建筑学 会計画系論文集, No. 458, pp. 171-177, 1994.4

4) 岡島達雄, 金 東永, 麓 和義, 内藤 昌: 構成部位・要素から夕た日本・韓国 伝統建築のイメージ特性 日本・韓国伝統建築空間のイメージ特性（その 2$)$ ， 日本建築学会計画系論文集, No. 464, pp. 209-214, 1994.10

5) 金東永, 犅島達雄, 簏 和義, 黄, 武達, 内藤 昌: 日本・台湾伝統建築空間 のイメージ特性, 日本建築学会計画系論文集, No. 475, pp. 203-208,1995.4

6) Lowenthal, D.: The American scene, Geographical Review, Vol 58, pp. 61-68, 1968

7) Tuan, Y.-F.: Visual bright: Exercises in interpretation. In Visual Blight in America (Commission on College Geography Resource Paper No. 23). Washington, D. C.: Association of American Geographers, 1973

8) Sonnenfeld, J.: Environmental perception and adaptation level in the arctic. In D. Lowenthal (Ed.), Environmental Perception and Behavior. Chicago: University of Chicago, Department of Geography, 1967

9) Ulrich, R. S.: Aesthetic and affective response to natural environment, In I. Altman and J. F. Wohlwill (Ed.), Behavior and the Natural Environment (pp. 107-110), Plenum, New York, 1983

10) Shafer, E. L. \& Tooby, M.: Landscape preferences: an international replication, Journal of Leisure Research, Vol. 5, pp. 60-65, 1973

11) Zube, E. H., \& Mills, L. V., Jr.: Cross-cultural explorations in landscape perception. In $E$. H. Zube (Ed.), Studies in Landscape Perception (pp. 167-174). Amherst: University of Massachusetts, Institute for Man and Environment, 1976

12) Ulrich, R. S.: Visual landscape preference: A model and application, Man- Environment Systems, Vol. 7, pp. 279-293, 1977

13) Tips, W. E. J., \& Sabasdisara, T.: Landscape preference evaluation and sociocultural background: A comparison among Asian countries, Journal of Environmental Management, Vol. 22, pp. 113-124, 1986

14) Nasar, J. L: Visual preferences in urban street scenes: A cross-cultural comparison between Japan and United States, Journal of Cross-Cultural Psychology, Vol. 15, pp. 79-93, 1984

15) Yang, B. \& Kaplan, R.: The perception of landscape style: a cross-cultural comparison, Landscape and Urban Planning, Vol. 19, pp. 251-262, 1990

16) Yang, B. \& Brown, T. J.: A cross-cultural comparison of preferences for landscape styles and landscape elements, Environment and Behavior, Vol. 24, pp. 471-507, 1992

17) Kaplan, R. \& Herbert, E. J.: Cultural and sub-cultural comparisons in preferences for natural settings, Landscape and Urban Planning, Vol. 14, pp. 281-293, 1987

18) $\mathrm{Yu}, \mathrm{C}$.: Cultural variations in landscape preference: Comparison among Chinese sub-groups and Western design experts, Landscape and Urban Planning, Vol 32, pp. $107-126,1995$

19) Herzog, T. R., Herbert, E. J., Kaplan, R. and Crooks, C. L: Cultural and developmental comparisons of landscape perceptions and preferences, Environment and Behavior, Vol. $32, p p .323-346,2000$

20) Purcell, A. T., Lamb, R. J., Peron, E. M. and Falchero, S.: Preference or preferences for landscape?, Journal of Environ- mental Psychology, Vol. 14, pp. 195-209, 1994

21) Peron, E., Purcell, A. T., Staats, H., Falchero, S. and Lamb, R.J.: Models of preference for outdoor scenes, Some experimental evidence, Environment and Behavior, Vol. 30, pp. $282-305,1998$

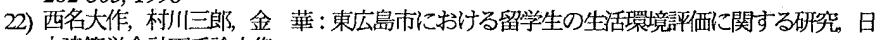
本建築学会計画系論文集, No. 529, pp. 101-108, 2000.3

23）金，華，村川三郎，西名大作:留学生と日本人住民による東広島市のみぞり景観 評価構造の比較，日本建築学会計画系論文集，No. 544, pp. 47-54, 2001.6

24）金 華, 西名大作, 村川三郎, 飯尾昭彦: 英国・日本・中国の被験者による河川 景観評洒構造の比較分析, 日本建築学会計画系論文集, No. 544, pp. 63-70, 2001.6

25) 藤井英二郎, 安藤敏夫, 金恩一: 植物の色彩と眼球運動及び脑波との関わりに つw

26) 古谷勝則，油井正昭，沼本健司，重南，児島隆政：自然景観にお灯万建筑物 の位置の変化と景観認識との関係に関する研究, 造園雑誌, No. 57, pp. 289-294, 1994

27) 村川三郎, 西名大作, 植木雅浩: 河川景観の画像特徵量之被験者注視点の関連, 日本建築学会計画系論文集, No. 479, pp. 67-76, 1996.1

28) 村川三郎, 西名大作, 植木雅浩, 横田幹朗河川景観の画像特徵量之被験者の心理 的評価構造の関連，日本建築学会計画系論文集，No. 524, p . 53-60, 1999.10

29）金 華, 村川三郎, 西名大作, 大石洋之: 被験者の注視特性による地域景観評価 構造の分析 その1 実駼概要および地域景観に対する心理的評伍, 日本建築学 会大会学術浾演梗摡集D-1, pp.765-766,2001.9

30) 大石洋之，村川三郎，西名大作，金 華 : 被験者の注視特性に上る地域景䳽評価 構造の分析 その2 地域景観に対する被験者の注視特性, 日本建築学会大会学 術講演梗概集D-1, pp. 767-768, 2001.9

31) 苧阪良三, 中满幸关, 古賀一夫: 眼球運動の実験心理学, 名古屋大学出版会, 1993 